\title{
SLIT-ROBO Rho GTPase-Activating Protein 3
}

National Cancer Institute

\section{Source}

National Cancer Institute. SLIT-ROBO Rho GTPase-Activating Protein 3. NCI Thesaurus.

Code C97799.

SLIT-ROBO Rho GT Pase-activating protein 3 (1099 aa, 125 kDa) is encoded by the human SRGAP3 gene. This protein plays a role in the signaling mediated by small GT Pases. 